\title{
RESEARCH PAPER \\ Yield, yield features, phytochemical composition, antioxidant and antibacterial activities of Abutilon indicum cultivated under different fertilizers
}

\author{
Gulsum Yaldiz', Arzu Birinci Yildirim¹, Yeliz Kasko Arici² and Mahmut \\ Camlica $^{1}$ \\ ${ }^{1}$ Abant Izzet Baysal University, Faculty of Agriculture and Natural Sciences, Department of Field Crops. \\ 14280 Bolu, Turkey. \\ ${ }^{2}$ Ordu University, Faculty of Agriculture, Department of Animal Science, Biometry-Genetics Unit. 52200 \\ Ordu, Turkey.
}

\begin{abstract}
G. Yaldiz, A. B. Yildirim, Y. K. Arici, and M. Camlica. 2016. Yield, yield features, phytochemical composition, antioxidant and antibacterial activities of Abutilon indicum cultivated under different fertilizers. Cien. Inv. Agr. 43(3):464-475. Abutilon indicum (Link) Sweet is an important medicinal plant that has been used in traditional medicine for centuries, and it is one of the novel crops being used in the pharmaceutical industry. Agricultural practices that produce high drug yield and desired secondary metabolites are in high demand by pharmaceutical-related industries; therefore, the aim of this study was to determine the leaf and seed yield, crude oil yield, crude oil composition, total phenolic content, and the antioxidant and antibacterial potential of A. indicum Sweet grown using two fertilizer applications: a three-component fertilizer containing nitrogen, phosphorus and potassium (NPK, 10-10-40) and calcium ammonium nitrate (CAN, $26 \% \mathrm{~N}$ ). In addition, the results were compared to a control group in which no fertilizer was used. Two experiments were conducted in two consecutive years, and the highest leaf and seed yields, $74250.0 \pm 5440.0 \mathrm{~kg} \mathrm{ha}^{-1}$ and $1159.6 \pm 62.2$ $\mathrm{kg} \mathrm{ha}^{-1}$, respectively, were obtained from the CAN application in both years. Seed crude oil content varied from 13.6 to $14.7 \%$, and linoleic acid (69.5\%) was the major crude oil acid in the seed oil, which reached higher values under the NPK than the CAN application. Both fertilizers were found to promote the highest antioxidant activity in the roots (87.2\%). In leaves, the highest phenolic compound content was observed in the control application (56.9 $\pm 0.0 \mathrm{mg} \mathrm{GAE} \mathrm{g}^{-1}$ dry extract), and the highest flavonoid content was detected in the CAN application (107.4 mg Pyrocatechol g-1 dry extract). Except the leaves extracts, the root and seed extracts of $A$. indicum Sweet had higher phenolic contents than the control application. For all of the analyzed extracts combined (leaf, root and seed), the fertilized plants had higher flavonoid contents than the control application. In addition, the root extracts of $A$. indicum Sweet exhibited the highest antibacterial activity against Streptococcus pyogenes.
\end{abstract}

Keywords: Biological activity, CAN, crude oil, fertilizer, NPK, yield.

\section{Introduction}

Increasing risks of infection stemming from antibiotic-resistant microorganisms have made

Received: May 18, 2016. Accepted: October 7, 2016. Corresponding author: g_yaldiz@hotmail.com the discovery of new and natural antimicrobial substances the focus of various studies, while the expectations of conscious consumers have encouraged or even forced drug producers and service providers to use natural preservatives. Thus, a need has arisen to investigate and test the efficacy of various plants against microorganisms, and the 
antibacterial impacts of various plant extracts on microorganisms and, particularly, food pathogens have been reported by several researchers (Prescott et al., 1990). It is well known that reactive oxygen compounds such as singlet oxygen, superoxide radicals, hydrogen peroxide, hydroxyl radicals and nitric oxide are unstable and extremely reactive, and oxidative stress-induced reactive oxygen species are considered indicators of the development and progress of various cardiovascular diseases. Antioxidants prevent the negative impacts of free radicals and reactive oxygen species and protect the body. Today, the most common synthetic antioxidants are butylated hydroxyltoluene (BHT), butylated hydroxylanisole (BHA), propyl gallate and tertiary butylhydroquinone (Fisherman and Cohen, 1973).

However, the use of synthetic antioxidants has been debated due to their toxic and carcinogenic effects, which can result in liver damage, so the discovery of new, reliable and harmless antioxidants from natural resources has become a prominent research topic (Birman, 2012). Abutilon indicum Sweet is an herbaceous and shrubby plant in the Malvaceae family that grows in tropical and subtropical regions, and it contains saponins, flavonoids, alkaloids and essential oil components such as $\beta$-sitosterol, $\beta$-amyrin, eudesmol, eugenol, geraniol and caryophyllene (Yasmin et al., 2008). Therefore, it has been used as a diuretic, pulmonaric, sedative, laxative, antilipidemic and an emollient in folk medicine (Tripathi et $a l ., 2012)$. The whole plant has also been used to cure blood dysentery and treat allergies, and the seeds are an efficient laxative and expectorant for cough treatment (Yasmin et al., 2008). The leaves have been used to treat throat ulcers, headaches, gonorrhea, and bladder infections and have been employed in the traditional phytotherapy of jaundice and hepatoprotective diseases (Porchezhian and Ansari, 2005). A. indicum roots are demulcents and diuretics that are prescribed for fever, chest infection and urethritis (Ponnudurai et al., 2011), and the plant has also been reported to have hepatoprotective (Porchezhian and Ansari,
2005; Tripathi et al., 2012), analgesic, antifertility, antifungal, antibacterial (Tripathi et al., 2012), immunological and anti-inflammatory (Yasmin et al., 2008) activities.

Fertilization is one of the most significant agricultural practices used to improve the yield and quality of traditional crops. Nitrogen is an essential element for plant development that is present in several chemical forms in nature and in chemical compounds such as ammonium, nitrate and urea. Chemical nitrogen fertilizer mixtures such as a three-component fertilizer containing nitrogen, phosphorus and potassium (NPK, 10-10-40) and calcium ammonium nitrate (CAN, 26\% N) are examples of combining these compounds. The availability of nitrogen in plants varies with the different forms and mixtures of nitrogen (Mattson and Leatherwood, 2009). In this study, the adaptability of $A$. indicum Sweet to the climatic conditions of the Eastern Black Sea region of Turkey was investigated by determining the leaf and seed yield, crude oil yield, crude oil composition, total phenolic content, and the antioxidant and antibacterial potential of this plant under different fertilizer applications.

\section{Materials and methods}

\section{Growth conditions}

Field experiments were carried out during two successive seasons (2012 and 2013) at Ordu University Experimental Farms (4058'36" N, 3759'55" E), located at an altitude of approximately $10 \mathrm{~m}$ above sea level. Climatic data were recorded for both years during the summer growing seasons (from April to August), and the means were as follows: a temperature of $19{ }^{\circ} \mathrm{C}, 270 \mathrm{~mm}$ of precipitation and $69 \%$ relative humidity. The soil in the experimental area was clay-loam with a $\mathrm{pH}$ value of 7.8 , organic matter content of $4.7 \%$, phosphorus content of $10.3 \mathrm{ppm}$ and potassium ratio of $235 \mathrm{ppm}$. The experiment was implemented in a randomized block design with three 
replications, and each experimental plot consisted of five 14-m long rows with an inter-row distance of $0.5 \mathrm{~m}$ and an inter-plant distance of $0.3 \mathrm{~m}$; the total number of plants in each plot was 75 . As the base fertilizer, NPK (25-15-0) was added at the rate of $60 \mathrm{~kg} \mathrm{ha}^{-1}$ during soil preparation, and the different experimental fertilizer applications, $100 \mathrm{~kg} \mathrm{ha}^{-1}$ CAN (26\% N) and $100 \mathrm{~kg} \mathrm{ha}^{-1}$ NPK (10-10-40), were the applied to the plots. In both years, the plants ripened after 90-100 days following the spring sowing and were then harvested twice a week until the end of the season. Before the harvest, the yield components, namely, plant height, the number of branches and the number of capsules in the main branches were measured, and laboratory analyses were then performed on the seeds, leaves and roots.

\section{Isolation of crude oil}

Seed crude oil yield was calculated on a $91 \%$ dry matter basis, and the oil content was determined using the Soxhlet method, in which seed samples were finely ground in a coffee grinder (manufactured by Bran, Punjab Engineering Works, Mohali, Punjab, India) and extracted with $n$-hexane in a Soxhlet apparatus over $8 \mathrm{~h}$ at a constant temperature of $80^{\circ} \mathrm{C}$ (James, 1995).

\section{GC-MS/FID analysis of crude oil composition}

Seed crude oil compositions were analyzed using gas chromatography (Agilent 7890A) coupled with a flame ionization detector and mass spectrometry (Agilent 5975C) with a capillary column (HP Innowax Capillary; $60.0 \mathrm{~m}$ x $0.25 \mathrm{~mm} ; 0.25 \mu \mathrm{m}$ film thickness). The compositions were diluted with hexane at a ratio of 1:50, and GC-MS/FID analyses were performed at the split mode of 50:1. The injection volume and temperature were adjusted to $1 \mathrm{~mL}$ and $250{ }^{\circ} \mathrm{C}$, respectively, and helium $(99.9 \%)$ was used as the carrier gas at a constant flow rate of $1 \mathrm{~mL} \mathrm{~min}{ }^{-1}$. The oven temperature was programmed to increase at a rate of $20^{\circ} \mathrm{C} / \mathrm{min}$ from $60^{\circ} \mathrm{C}$ for $10 \mathrm{~min}$ to $250{ }^{\circ} \mathrm{C}$ and then remain at this temperature for $8 \mathrm{~min}$. MS spectra were monitored within the range of 35$450 \mathrm{amu}$, and electronic impact at $70 \mathrm{eV}$ was used as the ionization mode. The relative percentage of the components was calculated from GC-FID peak areas, and the components were identified using the WILEY, NIST and FLAVOR libraries.

\section{Antibacterial properties of Abutilon}

Twenty-five $g$ of each harvested plant part were extracted with $300 \mathrm{~mL}$ methanol over $18 \mathrm{~h}$ in a water bath at $40{ }^{\circ} \mathrm{C}$ and then filtered. Filtrates were evaporated under a vacuum using a rotary evaporator and then dissolved in $10 \mathrm{~mL}$ of distilled water and lyophilized. All of the extracts were stored at $-20{ }^{\circ} \mathrm{C}$ until use (Table 1 ).

A disc diffusion assay (Kirby-Bauer Method) was performed to screen for antibiotic activity (Prescott and Harley, 1990), and the following gram positive bacterial strains were used: Streptococcus pyogenes, Staphylococcus aureus, and Staphylococcus epidermidis. BD-Microtrol discs (Becton Dickinson Laboratories, France) containing different bacterial strains were transferred to test tubes containing 2 $\mathrm{mL}$ of tryptic soy broth (TSB) and incubated for $3 \mathrm{~h}$ at $37^{\circ} \mathrm{C}$. After $3 \mathrm{~h}$, one bacteriological loop from each broth was streaked on tryptic soy agar (TSA) plates and incubated for 2 days at $37^{\circ} \mathrm{C}$, after which a single colony was removed and streaked on a new TSA plate and incubated at $37{ }^{\circ} \mathrm{C}$ for 2 additional days. Then, 4-5 loops of pure culture were transferred to $20 \mathrm{~mL}$ of TSB in a test tube for each bacterial strain and incubated overnight at $37^{\circ} \mathrm{C}$. Each bacteria broth culture was adjusted with saline to obtain a turbidity that was visually comparable to a $0.5 \mathrm{McFarland}$ standard, and Mueller Hinton agar plates for each bacterium were then inoculated using cotton swabs. All extracts were sterilized by filtering through a $0.22-\mathrm{mm}$ filter (Pal-Gelman Laboratory), and sterile filter paper discs (Glass Microfiber filters, Whatman ${ }^{\hat{a}}$; $7 \mathrm{~mm}$ in diameter) were impregnated with 13 
Table 1. Comparison of the agronomic properties and yield of $A$. indicum grown under different fertilizer applications.

\begin{tabular}{|c|c|c|c|c|c|c|}
\hline & Year & Control & NPK & CAN & Average & P-value \\
\hline \multirow{3}{*}{$\begin{array}{l}\text { Plant height } \\
(\mathrm{cm})\end{array}$} & 2012 & $137.7 \pm 3.8 \mathrm{Ba}$ & $178.1 \pm 19.1 \mathrm{ABa}$ & $216.4 \pm 17.0 \mathrm{Aa}$ & $177.4 \pm 13.6$ & \multirow{3}{*}{$\begin{array}{l}\text { Y:0.000 NS } \\
\text { T:0.010 NS } \\
\text { Y*T:0.038 }\end{array}$} \\
\hline & 2013 & $110.4 \pm 9.0 \mathrm{Aa}$ & $139.0 \pm 14.6 \mathrm{Aa}$ & $122.1 \pm 10.80 \mathrm{Ab}$ & $123.8 \pm 7.12$ & \\
\hline & Avr. & $124.1 \pm 7.5$ & $158.5 \pm 13.9$ & $169.2 \pm 22.9$ & & \\
\hline \multirow{3}{*}{$\begin{array}{l}\text { Number of } \\
\text { branches }\end{array}$} & 2012 & $6.2 \pm 0.3$ & $5.2 \pm 0.1$ & $6.9 \pm 1.2$ & $6.1 \pm 0.4 \mathrm{a}$ & \multirow{3}{*}{$\begin{array}{c}\mathrm{Y}: 0.013^{1} \\
\mathrm{~T}: 0.501 \mathrm{NS} \\
\mathrm{Y}^{*} \mathrm{~T}: 0.265 \mathrm{NS}\end{array}$} \\
\hline & 2013 & $4.6 \pm 0.2$ & $4.8 \pm 0.5$ & $4.5 \pm 0.3$ & $4.7 \pm 0.2 \mathrm{~b}$ & \\
\hline & Avr. & $5.4 \pm 0.4$ & $5.0 \pm 0.2$ & $5.7 \pm 0.8$ & & \\
\hline \multirow{3}{*}{$\begin{array}{l}\text { Number of seeds } \\
\text { per capsule }\end{array}$} & 2012 & $38.4 \pm 2.2$ & 40. $0 \pm 1.1$ & $40.4 \pm 0.7$ & $39.6 \pm 0.8 \mathrm{a}$ & \multirow{3}{*}{$\begin{array}{c}\mathrm{Y}: 0.001^{2} \\
\mathrm{~T}: 0.526 \mathrm{NS} \\
\mathrm{Y} * \mathrm{~T}: 0.446 \mathrm{NS}\end{array}$} \\
\hline & 2013 & $31.4 \pm 1.1$ & $27.5 \pm 0.5$ & $32.0 \pm 3.7$ & $30.3 \pm 1.3 \mathrm{~b}$ & \\
\hline & Avr. & $34.9 \pm 1.9$ & $33.8 \pm 2.9$ & $36.3 \pm 2.5$ & & \\
\hline \multirow{3}{*}{$\begin{array}{l}\text { Seed weight per } \\
\text { plant }(\mathrm{g})\end{array}$} & 2012 & $13.4 \pm 0.8$ & $14.4 \pm 0.7$ & $14.5 \pm 1.2$ & $14.1 \pm 0.45 \mathrm{a}$ & \multirow{3}{*}{$\begin{array}{c}\mathrm{Y}: 0.004^{2} \\
\mathrm{~T}: 0.633 \mathrm{NS} \\
\mathrm{Y}^{*} \mathrm{~T}: 0.552 \mathrm{NS}\end{array}$} \\
\hline & 2013 & $9.4 \pm 0.7$ & $10.7 \pm 0.6$ & $7.8 \pm 3.3$ & $9.3 \pm 1.1 \mathrm{~b}$ & \\
\hline & Avr. & $11.4 \pm 1.0$ & $12.5 \pm 0.9$ & $11.2 \pm 2.1$ & & \\
\hline \multirow{3}{*}{$\begin{array}{l}1000 \text {-seed } \\
\text { weight } \\
(\mathrm{g})\end{array}$} & 2012 & $11.1 \pm 0.1$ & $10.7 \pm 0.2$ & $11.7 \pm 0.1$ & $11.2 \pm 0.2 \mathrm{a}$ & \multirow{3}{*}{$\begin{array}{c}\mathrm{Y}: 0.000^{3} \\
\mathrm{~T}: 0.034^{1} \\
\mathrm{Y}^{*} \mathrm{~T}: 0.781 \mathrm{NS}\end{array}$} \\
\hline & 2013 & $8.4 \pm 0.4$ & $8.1 \pm 0.6$ & $9.5 \pm 0.3$ & $8.7 \pm 0.3 \mathrm{~b}$ & \\
\hline & Avr. & $9.7 \pm 0.6 \mathrm{AB}$ & $9.4 \pm 0.7 \mathrm{~B}$ & $10.6 \pm 0.5 \mathrm{~A}$ & & \\
\hline \multirow{3}{*}{$\begin{array}{l}\text { Capsule breadth } \\
(\mathrm{cm})\end{array}$} & 2012 & $0.6 \pm 0.0$ & $0.7 \pm 0.0$ & $0.7 \pm 0.0$ & $0.67 \pm 0.0 \mathrm{a}$ & \multirow{3}{*}{$\begin{array}{c}\mathrm{Y}: 0.000^{2} \\
\mathrm{~T}: 0.357 \mathrm{NS} \\
\mathrm{Y}^{*} \mathrm{~T}: 0.661 \mathrm{NS}\end{array}$} \\
\hline & 2013 & $0.5 \pm 0.1$ & $0.6 \pm 0.0$ & $0.6 \pm 0.0$ & $0.56 \pm 0.0 \mathrm{~b}$ & \\
\hline & Avr. & $0.6 \pm 0.0$ & $0.6 \pm 0.0$ & $0.6 \pm 0.0$ & & \\
\hline \multirow{3}{*}{$\begin{array}{l}\text { Capsule length } \\
(\mathrm{cm})\end{array}$} & 2012 & $0.6 \pm 0.0$ & $0.6 \pm 0.0$ & $0.6 \pm 0.0$ & $0.56 \pm 0.0 \mathrm{a}$ & \multirow{3}{*}{$\begin{array}{c}\text { Y:0.0072 } \\
\text { T: } 0.789 \mathrm{NS} \\
\mathrm{Y}^{*} \mathrm{~T}: 0.996 \mathrm{NS}\end{array}$} \\
\hline & 2013 & $0.5 \pm 0.0$ & $0.5 \pm 0.0$ & $0.4 \pm 0.0$ & $0.5 \pm 0.0 \mathrm{~b}$ & \\
\hline & Avr. & $0.5 \pm 0.0$ & $0.5 \pm 0.0$ & $0.5 \pm 0.0$ & & \\
\hline \multirow{3}{*}{$\begin{array}{l}\text { Fresh leaf yield } \\
\left(\mathrm{kg} \mathrm{ha}^{-1}\right)\end{array}$} & 2012 & $62050.0 \pm 2720.0$ & $64643.0 \pm 852.0$ & $74250.0 \pm 5440.0$ & $66980.0 \pm 2570.0 \mathrm{a}$ & \multirow{3}{*}{$\begin{array}{c}\mathrm{Y}: 0.002^{2} \\
\mathrm{~T}: 0.006^{2} \\
\mathrm{Y} * \mathrm{~T}: 0.971 \mathrm{NS}\end{array}$} \\
\hline & 2013 & $51870.0 \pm 1870.0$ & $53143.0 \pm 996.0$ & $63680.0 \pm 3190.0$ & $56230.0 \pm 2170.0 \mathrm{~b}$ & \\
\hline & Avr. & $56960.0 \pm 2710.0 \mathrm{~B}$ & $58890.0 \pm 2640.0 \mathrm{~B}$ & $68970.0 \pm 3680.0 \mathrm{~A}$ & & \\
\hline \multirow{3}{*}{$\begin{array}{l}\text { Dry leaf yield } \\
(\mathrm{kg} / \mathrm{ha})\end{array}$} & 2012 & $15730.0 \pm 1140.0$ & $15416.0 \pm 366.0$ & $19410.0 \pm 2000.0$ & $16850.0 \pm 929.0 \mathrm{a}$ & \multirow{3}{*}{$\begin{array}{c}\mathrm{Y}: 0.026^{1} \\
\mathrm{~T}: 0.007^{2} \\
\mathrm{Y}^{*} \mathrm{~T}: 0.879 \mathrm{NS}\end{array}$} \\
\hline & 2013 & $14060.0 \pm 1480.0$ & $12730.0 \pm 102.0$ & $17070.0 \pm 1010.0$ & $14619.0 \pm 875.0 \mathrm{~b}$ & \\
\hline & Avr. & $14893.0 \pm 916.0 \mathrm{~B}$ & $14075.0 \pm 772.0 \mathrm{~B}$ & $18240.0 \pm 1130.0 \mathrm{~A}$ & & \\
\hline \multirow{3}{*}{$\begin{array}{l}\text { Seed yield (kg/ } \\
\text { ha) }\end{array}$} & 2012 & $794.0 \pm 40.2$ & $1023.3 \pm 18.2$ & $1159.6 \pm 62.2$ & $992.2 \pm 57.7 \mathrm{a}$ & \multirow{3}{*}{$\begin{array}{c}\mathrm{Y}: 0.000^{3} \\
\mathrm{~T}: 0.006^{2} \\
\mathrm{Y}^{*} \mathrm{~T}: 0.095 \mathrm{NS}\end{array}$} \\
\hline & 2013 & $667.0 \pm 25.0$ & $716.3 \pm 71.4$ & $760.3 \pm 91.9$ & $714.6 \pm 36.9 \mathrm{~b}$ & \\
\hline & Avr. & $731.0 \pm 35.4 \mathrm{~B}$ & $869.8 \pm 76.1 \mathrm{AB}$ & $960.0 \pm 102.0 \mathrm{~A}$ & & \\
\hline
\end{tabular}

$\mathrm{Y}$, year; $\mathrm{T}$, treatment; $\mathrm{Y}^{*} \mathrm{~T}$, year*treatment interaction; mean $\pm \mathrm{SEM}$; NS: not statistically significant $(\mathrm{P}>0.05)$.

${ }^{1}$ Statistically significant $(\mathrm{P} \leq 0.05) ;{ }^{2}$ statistically significant $(\mathrm{P} \leq 0.01) ;{ }^{3}$ statistically significant $(\mathrm{P} \leq 0.001)$.

Horizontally, means that do not share a capital letter are significantly different from each other $(\mathrm{P} \leq 0.05)$.

Vertically, means that do not share a lowercase letter are significantly different from each other $(\mathrm{P} \leq 0.05)$. 
$\mu \mathrm{L}$ of extract. There were five replicates on each plate, and two plates for each extract were tested for each bacterium. Positive controls consisted of two different antimicrobial susceptibility test discs (Bioanalysễ ): ampicillin (10 mg) (AM-10) and tetracycline (30 mg) (TE-30). Two antibiotic discs were used for each plate and run in duplicate, and the negative control was water. Inoculated plates with discs were placed in a $37^{\circ} \mathrm{C}$ incubator. After 16 to $18 \mathrm{~h}$ of incubation, the diameter $(\mathrm{mm})$ of the inhibition zone was measured. All experiments were repeated three times.

\section{Antioxidant properties of Abutilon}

The free radical scavenging activity of the methanolic extracts of $A$. indicum Sweet leaves, roots and seeds was determined spectrophotometrically by monitoring the disappearance of 2,2-diphenyl1-picrylhydrazyl (DPPH) at $517 \mathrm{~nm}$, according to the method described by Brand-Williams et al. (1995). Briefly, a 0.15-mM solution of DPPH was prepared in methanol, and $1 \mathrm{~mL}$ of this solution was then added to $3 \mathrm{~mL}$ of the extracts at different concentrations $\left(25,50,100\right.$ and $\left.200 \mu \mathrm{g} \mathrm{mL}^{-1}\right)$. These solutions were incubated in the dark, and the absorbance of each was measured at $517 \mathrm{~nm}$ against blank samples using a 200-V Hitachi U-1900 UV-VIS spectrophotometer. All analyses were performed in triplicate, and the DPPH scavenging capacity of the extracts was calculated using the following equation (Gulcin et al., 2003):

DPPH $\cdot$ Scavenging Effect $(\%$ inhibition $)=\left[\left(\mathrm{A}_{0}-\mathrm{A}_{1} /\right.\right.$ $\left.\left.\mathrm{A}_{0}\right) \times 100\right]$

$\mathrm{A}_{0}$ : Absorbance of the control reaction

$A_{1}$ : Absorbance in the presence of the tested extracts

\section{Phenolic content of Abutilon}

The total phenolic content in the methanolic extracts of $A$. indicum Sweet leaves, roots and seeds was determined by the procedure described by Slinkard and Singleton (1977) with the slight modification of using a Folin-Ciocalteu phenolic reagent. Gallic acid was used as a standard phenolic compound. Briefly, $2 \mathrm{~mL}$ of distilled water were added to $0.01 \mathrm{~g}$ of the $A$. indicum extracts ( $5 \mathrm{mg} \mathrm{mL}^{-1}$ ), and the prepared stock solution was then diluted to $1 \mathrm{mg} \mathrm{mL}^{-1}$. To prepare a calibration curve, solutions of $0,25,50,100,150$ and $200 \mathrm{mg} \mathrm{L}^{-1}$ gallic acid were prepared, and 20 $\mu \mathrm{L}$ from each calibration solution, sample, or blank were placed into separate cuvettes. Then, $1.58 \mathrm{~mL}$ of water and $100 \mu \mathrm{L}$ of Folin-Ciocalteu reagent $\left(\right.$ Sigma $\left.^{\circledR}\right)$ were added to each cuvette and mixed well. After 2 minutes, $300 \mu \mathrm{L}$ of $\mathrm{Na}_{2} \mathrm{CO}_{3}$ solution were added to the mix and thoroughly shaken. These solutions were incubated at $20^{\circ} \mathrm{C}$ for $2 \mathrm{~h}$, and the absorbance of each solution was measured at $765 \mathrm{~nm}$ against the blank using a spectrophotometer. The amounts of total phenolic compounds in $A$. indicum leaf, root and seed extracts were determined as micrograms of gallic acid equivalent (GAE) using an equation obtained from a standard gallic acid graph $\left(R^{2}: 0.9957\right)$. All of the analyses were performed in triplicate.

\section{Flavonoid content of Abutilon}

The total flavonoid content in the methanolic extracts of $A$. indicum leaves, roots and seeds was measured by aluminum chloride $\left(\mathrm{AlCl}_{3}\right)$ colorimetric assay. Catechol was used as a reference flavonoid, and 2500 and $1250 \mathrm{mg} \mathrm{mL}^{-1}$ concentrations of the extracts were prepared in ethanol. Different catechol concentrations (20, 40, 60,80 and $100 \mathrm{mg} \mathrm{mL}^{-1}$ ) were prepared to obtain a standard catechol calibration curve. Briefly, 500 $\mu \mathrm{L}$ of extract solution or standard catechol solution was added to a $10-\mathrm{mL}$ test tube containing $2 \mathrm{~mL}$ of distilled water, and $150 \mu \mathrm{L}$ of $5 \% \mathrm{NaNO}_{2}$ was then added to each test tube. After $5 \mathrm{~min}, 150 \mu \mathrm{L}$ of $10 \% \mathrm{AlCl}_{3}$ was added, and at $6 \mathrm{~min}, 1000 \mu \mathrm{L}$ of $1 \mathrm{M} \mathrm{NaOH}$ was added to the mixture followed by dilution to a volume of $5 \mathrm{~mL}$ by adding 1200 $\mu \mathrm{L}$ of distilled water and mixing thoroughly. The 
absorbance of the mixture was determined at 510 $\mathrm{nm}$ against a blank. The samples were analyzed in three replicates (Marinova et al., 2005), and the total flavonoid contents of $A$. indicum leaf, root and seed extracts were given as $\mathrm{mg}$ catechol equivalents (CE) per $100 \mathrm{~g}^{-1}$ extract dry weight.

\section{Statistical analysis}

Anderson-Darling and Bartlett tests were applied to test normality and homogeneity of variance, respectively. Agronomic parameters were analyzed by two-way ANOVA (with repeated block experiments in different years), and the seed crude oils were analyzed by one-way ANOVA. The means were compared with the Tukey HSD test, and the results are displayed as letters associated with the mean. All parameter values are expressed as the mean \pm standard error of the mean (SEM)/standard deviation (SD), and the alpha level was set at $5 \%$. The statistical analysis was performed using the Minitab v17 (Minitab Inc., State

College, Pennsylvania, USA). The results of the antibacterial bioassays were statistically analyzed using ANOVA and Duncan's multiple range test.

\section{Results}

\section{Plant development}

Based on the data obtained from the field trial, there were no significant differences in the plant height of $A$. indicum between fertilizer applications. The highest plant height value was obtained from the CAN application in the first year, while in the second year, it was obtained from NPK. The number of branches varied from 4.5 to 6.9 branches plant ${ }^{-1}$, with the highest average number obtained in the CAN fertilizer treatment. The number of seeds per capsule ranged from 27.5 to 40.4 , with the highest value observed with CAN and the lowest with NPK. There were no significant differences between fertilizer applica- tions in terms of the seed weight, but the highest thousand-seed weight was obtained from the CAN fertilizer application, while the lowest was observed in the NPK application. The thousandseed weight was different between the first and second experimental years with higher values in the first year.

The average capsule width varied between 0.5 and $0.7 \mathrm{~cm}$, and the highest value was obtained from both fertilizer applications. In both experimental years, the length of the capsule grown under different fertilizer applications ranged from 0.4 to $0.6 \mathrm{~cm}$, with the longest capsule obtained from the CAN application in the first year, and the shortest capsule was obtained from the control in the second year. The $A$. indicum fresh leaf yield was significantly different between the two years, ranging from 51.870 to $74.250 \mathrm{~kg} \mathrm{ha}^{-1}$ with the different applications. The highest leaf yield was obtained from the CAN application in both years, and the lowest total fresh herbal weight was from the control application: $62.050 \mathrm{~kg} \mathrm{ha}^{-1}$ in the first year and $51.870 \mathrm{~kg} \mathrm{ha}^{-1}$ in the second year. The highest dry leaf yield was obtained from the CAN application: 19.410 and $17.070 \mathrm{~kg}$ $\mathrm{ha}^{-1}$ in the first and second years, respectively. The lowest dry leaf yield was obtained from the NPK treatment in both years, 15.410 and 12.730 $\mathrm{kg} \mathrm{ha}^{-1}$, respectively.

Although there were significant differences between years in terms of seed yields, no significant differences were observed between the fertilizer applications. In the present study, the seed yield of $A$. indicum ranged widely from 667 to 1159.6 $\mathrm{kg} \mathrm{ha}^{-1}$ with the highest seed yield obtained from the CAN application (Table 1).

\section{Chemical properties of crude oil}

Table 2 presents the chemical properties of $A$. indicum crude oil by fertilizer treatment, and there were significant differences in seed crude oil content between the fertilizer applications. 
The crude oil content ranged from 13.6 to $14.7 \%$, with the highest value observed with the NPK application. Different fertilizer applications had a statistically significant effect on seed crude oil acids, except for the palmitic and linolenic acids. Among the fertilizer applications that statistically affected the crude oil acid contents, NPK yielded the highest values (Table 2).

\section{Antibacterial properties}

Nine different plant extracts (leaf, root and seed $\mathrm{MeOH}$ extract of $A$. indicum grown in $\mathrm{CAN}$ - and NPK-treated and control soils) were screened for antibacterial activity. Bacterial growth was generally sensitive to the tested reference antibiotics, and no inhibition was observed with the extraction solvent (water). All methanol extracts only exhibited antibacterial activity against $S$. pyogenes, and when compared to chloramphenicol (reference antibiotic) $(37.0 \pm 1.7 \mathrm{~mm})$, the extracts showed lower antibacterial activity. Among the leaf, root and seed methanol extracts, the root extracts had the highest antibacterial activity against $S$. pyogenes, and the CAN and control extracts exhibited higher activity in the root (11.5and $11.3-\mathrm{mm}$ inhibition zone, respectively) than the NPK extract (9.5-mm inhibition zone). The tested methanol extracts displayed no antibacterial activity against $S$. aureus or $S$. epidermidis.

\section{Antioxidant properties and secondary metabolite contents}

The antioxidant activity of the methanolic extracts of $A$. indicum leaves, roots and seeds grown in soils treated with CAN or NPK and the control were examined using the DPPH scavenging method. The results indicated that at a minimum concentration $\left(25 \mu \mathrm{g} \mathrm{mL}^{-1}\right)$, all of the extracts had less than 50\% DPPH radical scavenging activity, but when used at a concentration of $50 \mu \mathrm{g} \mathrm{mL}^{-1}$, the control leaf and NPK root extracts displayed higher radical scavenging activities (60.6 and $52.4 \%$, respectively) than the other extracts.

At $100 \mu \mathrm{g} \mathrm{mL}^{-1}$ and above, all of the leaves extracts, except CAN leaf extracts, exhibited scavenging activities greater than 50\% DPPH (Table 3); in other words, the extracts obtained from $A$. indicum seed treated with CAN, NPK or grown on control soils had little tendency to scavenge DPPH radicals compared to the other extracts. When leaves grown on CAN- and NPK-treated and control soils were compared, the control leaf extract showed the highest DPPH radical scaveng-

Table 2. Comparison of the crude oil yield and composition of A. indicum seeds (\%) grown under different fertilizer applications.

\begin{tabular}{lccccc}
\hline & \multicolumn{3}{c}{ Soil treatment } & \multirow{2}{*}{ P-value } \\
\cline { 2 - 5 } Variables & RT & Control & NPK & CAN & $0.004^{1}$ \\
\hline Seed crude oil content & - & $13.6 \pm 0.1 \mathrm{~B}$ & $14.7 \pm 0.1 \mathrm{~A}$ & $13.6 \pm 0.3 \mathrm{~B}$ & $0.465 \mathrm{NS}$ \\
Palmitic acid (C16:0) & 16.4 & $15.6 \pm 0.0$ & $15.9 \pm 0.1$ & $15.5 \pm 0.2$ & $0.005^{1}$ \\
Palmitoleic acid (C16:1) & 16.9 & $0.3 \pm 0.0 \mathrm{~B}$ & $0.4 \pm 0.0 \mathrm{~A}$ & $0.4 \pm 0.0 \mathrm{~B}$ & $0.276 \mathrm{NS}$ \\
Stearic acid (C18:0) & 20.2 & $3.0 \pm 0.0$ & $3.0 \pm 0.0$ & $2.9 \pm 0.0$ & $0.000^{2}$ \\
Oleic acid (C18:1) & 20.7 & $11.1 \pm 0.0 \mathrm{~B}$ & $11.9 \pm 0.0 \mathrm{~A}$ & $10.9 \pm 0.1 \mathrm{C}$ & $0.000^{2}$ \\
Linoleic acid (C18:2) & 21.7 & $69.2 \pm 0.0 \mathrm{~A}$ & $69.5 \pm 0.1 \mathrm{~A}$ & $67.9 \pm 0.1 \mathrm{~B}$ & $0.264 \mathrm{NS}$ \\
Linolenic acid (C18:3) & 23.0 & $0.8 \pm 0.0$ & $0.8 \pm 0.0$ & $0.8 \pm 0.0$ & \\
\hline
\end{tabular}

NS: Not statistically significant $(\mathrm{P}>0.05)$.

${ }^{1}$ Statistically significant $(\mathrm{P} \leq 0.01) ;{ }^{2}$ statistically significant $(\mathrm{P} \leq 0.001)$.

Means that do not share a letter are significantly different from each other $(\mathrm{P} \leq 0.05)$.

RT: Retention time. 
ing activity at all of the studied concentrations. Among the fertilizer applications, leaves treated with NPK showed higher DPPH scavenging activity than leaves treated with CAN. When roots treated with CAN and NPK and the control were compared, the CAN and NPK root extracts showed higher DPPH scavenging activities than the control root extract.

Table 4 presents the total phenolic and flavonoid contents of the leaf, root and seed extracts grown on soil treated with CAN and NPK and the control. The control leaf extract possessed the highest concentration of phenolic compounds $(56.9 \pm 0.0$ mg GAE $g^{-1}$ dry extract) compared to the other extracts followed by the leaf and root extracts grown on the NPK soil (46.4 and 46.1 mg GAE $\mathrm{g}^{-1}$ dry extract, respectively). The seed extracts grown on CAN and NPK soil had higher phenolic compound contents (15.1 and $20.5 \mathrm{mg} \mathrm{GAE} \mathrm{g}^{-1}$ dry extract, respectively) than the control seed extract, and similarly, when the root extracts were compared, the CAN and NPK treatments yielded higher phenolic contents (41.8 and $46.1 \mathrm{mg}$ GAE $\mathrm{g}^{-1}$ dry extract, respectively) than the control root extract. However, among the leaf extracts, the control leaf extract had a higher phenolic content (56.9 $\mathrm{mg} \mathrm{GAE} \mathrm{g}^{-1}$ dry extract) than the CAN and NPK leaf extracts (Table 4).

The CAN leaf extract was found to possess the highest flavonoid content (107.4 and $84.6 \mathrm{mg}$ pyrocatechol $\mathrm{g}^{-1}$ dry extract), and the CAN and NPK leaf, root and seed extracts had higher flavonoid contents than all of the control extracts. In addition, the CAN leaf and seed extracts contained a higher flavonoid percentage compared to the NPK extracts. In contrast, the NPK root extract had a higher flavonoid content than the CAN root extract (Table 4).

\section{Discussion}

When the results from this study are compared to those of previous reports, there are some similarities and differences. In the present study, plant height ranged from 110.4 to $216.4 \mathrm{~cm}$ with the different fertilizer applications, while this range is between 100 and $200 \mathrm{~cm}$ in other studies (Sharma et al., 2013). Parrish and Bazzaz (1985) reported the number of seeds in each capsule to be 16.5-31.5, with the nutritional value increasing as the number of capsules increased, but in the present study, the capsule number was found to be much higher. These differences are not surprising since plant properties are highly dependent on environmental conditions and the agricultural techniques being applied. In the present study, the highest agronomical and yield properties were obtained from the CAN treatment followed by the NPK and control applications (Table 1). There are many scientific reports showing that fertilizers containing a higher level of nitrogen improve the yield and yield components (Zareie et al., 2011); similarly, the CAN fertilizer that had the highest nitrogen content $(26 \% \mathrm{~N})$ produced the highest average yield value in the present study (Table 1). However, the highest crude oil content and most desired crude oil composition were obtained from the NPK fertilizer treatment. Some studies have reported that potassium has a positive effect on the secondary metabolite content in plants (Hu and Schmidhalter, 2005), and we obtained higher values of secondary metabolites with $\mathrm{K}$ fertilization (Table 2). The major components of A. indicum seed oil were identified as linoleic, oleic, stearic and palmitic acids, and this result is consistent with earlier reports (Sharma et al., 2013). These oil components promoted antioxidant activity, as reported in previous studies (Yasmin et al., 2008; Tripathi et al., 2012), and oleic acid may also play an important role in the treatment of heart disease (Singh and Gupta, 2008).

In this study, all of the methanol extracts only exhibited antibacterial activity against $S$. pyogenes, and the highest antibacterial activity was observed by the root extract from the CAN fertilizer treatment against $S$. pyogenes. Yasmin et al. (2008) reported that the root parts of $A$. indicum exhibited greater antibacterial activity against Micrococcus luteus, Bacillus subtilis, Escherichia 
Table 3. Free-radical (DPPH•) scavenging activity (\%) of the methanolic extracts of $A$. indicum leaves, seeds and roots and of ascorbic acid (positive control) grown under different fertilizer applications.

\begin{tabular}{lcccc}
\hline & \multicolumn{2}{c}{ Concentration $\left(\mu \mathrm{g} \mathrm{mL}{ }^{-1)}\right.$} \\
\cline { 2 - 5 } Treatments & 25 & 50 & 100 & 200 \\
\hline Ascorbic acid & 95.8 & 96.8 & 97.6 & 97.3 \\
CAN Leaf & 5.7 & 20.7 & 21.4 & 42.7 \\
NPK Leaf & 14.8 & 38.5 & 73.3 & 80.7 \\
Control Leaf & 20.5 & 60.6 & 78.2 & 86.7 \\
CAN Seed & 10.6 & 14.9 & 18.7 & 31.0 \\
NPK Seed & 13.7 & 13.7 & 13.4 & 27.7 \\
Control Seed & 10.0 & 13.7 & 18.5 & 19.3 \\
CAN Root & 20.8 & 40.0 & 60.3 & 87.2 \\
NPK Root & 43.1 & 52.4 & 81.1 & 87.2 \\
Control Root & 20.0 & 36.3 & 54.1 & 75.8 \\
\hline
\end{tabular}

Table 4. Total phenolic and flavonoid contents of the methanolic extracts of $A$. indicum leaves, seeds and roots grown under different fertilizer applications.

\begin{tabular}{lccccccc}
\hline & Leaf & Seed & Root & & Leaf & Seed & Root \\
\cline { 2 - 3 } Soil treatment & \multicolumn{2}{c}{ Total phenolics per mg GA g-1 } & dry extract & & Total flavonoids per mg pyrocatechol g-1 dry extract \\
\hline CAN & $34.7 \pm 0.0$ & $15.1 \pm 0.0$ & $41.8 \pm 0.0$ & & $107.4 \pm 0.0$ & $76.1 \pm 0.0$ & $47.7 \pm 0.0$ \\
NPK & $46.4 \pm 0.0$ & $20.5 \pm 0.0$ & $46.1 \pm 0.0$ & & $84.6 \pm 0.0$ & $26.2 \pm 0.0$ & $86.8 \pm 0.0$ \\
Control & $56.9 \pm 0.0$ & $14.5 \pm 0.0$ & $33.5 \pm 0.0$ & & $61.7 \pm 0.0$ & $13.2 \pm 0.0$ & $24.8 \pm 0.0$ \\
\hline
\end{tabular}

Mean \pm SD.

coli and Bacillus licheniformis compared to the leaf and seed extracts, which is consistent with the results of the present study.

Similar to the present findings, Raman et al. (2009) reported that methanol, ethanol and mixed (methanol: chloroform: water) $\mathrm{A}$. indicum extracts showed no antibacterial activity against $S$. aureus and the tested microorganisms. Abdul et al. (2010) also indicated that n-hexane and methanol fraction extracts were not active against $S$. aureus, and the chloroform fraction extract only exhibited antimicrobial activity against Sarcina lutea $(8.4 \mathrm{~mm})$. In contrast to our findings, Gurumurthy et al. (2011) reported that the methanolic extract of $A$. indicum had potent antibacterial effects on $S$. aureus, and Ranjit et al. (2013) indicated that the chloroform extract of A. indicum leaves showed antimicrobial activity against gram (+) microorganisms $(19.3 \pm 0.5 \mathrm{~mm}$ in diameter against $S$. aureus). In our study, each bacterium was inoculated on Muller Hinton Agar plates, and filter paper discs were impregnated with $13 \mathrm{~mL}$ of methanol extract, whereas the above-mentioned researchers used nutrient agar media for the microorganism inoculum and impregnated discs with higher volumes of the extracts $(20$ or $100 \mu \mathrm{L})$. It is obvious that differences in the extraction methods, extract concentrations and bacteriological media affected the biological activity results. The leaves of $A$. indicum exhibited good antioxidant activity in the NPK and control applications while the highest antioxidant activity among the $A$. indicum root extracts was observed in the NPK and CAN plots at a concentration of $200 \mu \mathrm{g}$ $\mathrm{mL}^{-1}$ (Table 3). The total phenolic and flavonoid contents of $A$. indicum varied with the fertilizer application, with the highest value found in both the NPK and CAN treatments, and the highest 
phenolic and flavonoid contents were observed in the leaf extracts (Table 4). Thus, based on the content of secondary metabolites, the fertilized plants had higher biological activity. Similarly, Sharma et al. (2013) evaluated the free radical scavenging activity based on the nitric oxide and superoxide radical scavenging activities and found the maximum values to be $28.74 \%$ and $49.62 \%$, respectively, at a concentration of $250 \mu \mathrm{g} \mathrm{mL}^{-1}$.

The total phenolic and flavonoid contents of $A$. indicum have also been investigated by other researchers to assess antioxidant capacity. Chakraborthy and Ghorpade (2010) reported that the total phenolic contents of $A$. indicum stem extracts (methanolic, hydro-alcoholic and aqueous), as measured by Folin Ciocalteu reagents in terms of a gallic acid equivalent (GAE), were 20.94, 27.77 and $35.45 \mathrm{mg} \mathrm{g}^{-1}$, respectively. Furthermore, with DPPH at IC50 (the concentration that inhibits $50 \%$ of the DPPH radical), the authors reported that the methanolic, hydro-alcoholic and aqueous extracts had values of 1343.89, 2487.14 and $1154.20 \mu \mathrm{g} \mathrm{mL}^{-1}$, respectively. In the study by Pandaya et al. (2013), the $A$. indicum extracts demonstrated a free radical scavenging potential, with IC50 values ranging from 53.08 to 364.94 $\mu \mathrm{g} \mathrm{mL} \mathrm{m}^{-1}$, and the highest free radical scavenging activity was observed in the hexane soluble fraction $\left(\mathrm{IC} 50=53.08 \pm 0.38 \mu \mathrm{g} \mathrm{mL}^{-1}\right)$, which may be due to its phenolic content, $57.9 \pm 0.58 \mathrm{mg}$ of GAE gm ${ }^{-1}$ of extract (Pandaya et al., 2013). Although the present findings are similar to previous results, there were differences among the studies in the methods used to extract $A$. indicum and evaluate antioxidant activity as well as the climate, soil, and environmental factors; diseases and pesticide treatments; harvest time; the drying and storage processes; and the plant parts used in the analyses, all of which may have significantly affected the antioxidant activity of the plants (Chakraborthy and Ghorpade, 2010). Several studies have demonstrated the relationship between antioxidant activity and plant phenolic content (Canadanović-Brunet et al., 2008), and in the current study, a positive correlation was found between total phenolic content and the antioxidant activity of all the plant extracts.

The main conclusions are as follows. Over the two experimental years of this study, the yield and yield components varied little with higher yields obtained in the first year. Among all of the analyzed extracts (leaf, root and seed), the fertilized plants had higher chemical contents and greater biological activity than the control plants. The CAN fertilizer treatment was particularly effective in terms of improving the yield and yield features, while NPK performed better in terms of the crude oil compositions.

It can be concluded from the present study that root and leaf extracts from $A$. indicum plants exhibit significantly higher phenolic contents and show promising free radical scavenging effects on DPPH in a concentration-dependent manner. In addition, the current findings reconfirmed those of earlier studies that found A. indicum to be a reliable natural antioxidant that can safely be used in the pharmaceutical and food industries to prevent the effects of reactive oxygen species and reduce the risks of cardiovascular disease. Thus, the extracts of the roots and leaves of $A$. indicum can play an important role in the prevention of several degenerative diseases, such as hepatic disorders, immune dysfunction, cataracts and macular degeneration, by inhibiting the production of reactive oxygen species, thus reducing the risk of these diseases and promoting proper organ function. 


\section{Resumen}

G. Yaldiz, A. B.Yildirim, Y. K. Arici y M. Camlica. 2016. Rendimiento, características del rendimiento, composición fitoquímico, actividad antioxidante y antibacteriana del Abutilon indicum cultivado con diferentes formas de aplicación de fertilizantes. Cien. Inv. Agr. 43(3):464-475. El Abutilon indicum (Link) Sweet es una importante planta medicinal que se ha empleado durante siglos en la medicina tradicional y una de las novedades en cultivos de la industria farmacéutica. Las prácticas agrarias que producen un alto rendimiento de componentes de plantas secados al aire libre ('drog') y los metabolitos secundarios deseados están muy demandadas por las industrias asociadas. De este modo, el objeto del estudio consistía en determinar el rendimiento de la hoja y la semilla del Abutilon indicum Sweet, el rendimiento y composición de su aceite crudo, su contenido fenólico total y su potencial antioxidante y antibacteriano empleando para ello las dos aplicaciones de fertilizante que figuran a continuación: un fertilizante de tres componentes (nitrógeno, fósforo y potasio; NPK, 10-10-40) y nitrato de amonio y calcio (CAN, 26\% N). Además, los resultados se han comparado con el grupo de control, sin fertilizante. Los dos experimentos se llevaron a cabo en dos años consecutivos. Los rendimientos más altos tanto de hoja como la semilla se obtuvieron en ambos años con la aplicación del CAN, con unos resultados de 74250.0 55440.0 y $1159.6 \pm 62.2 \mathrm{~kg} \mathrm{ha}^{-1}$, respectivamente. El contenido de aceite crudo de la semilla varió del 13.6 al 14.7\%. El ácido linoleico (69.5\%) fue el ácido graso predominante en el aceite de la semilla, alcanzando valores mayores con la aplicación del NPK comparado con CAN. Ambos fertilizantes presentaron la mayor actividad antioxidante en las raíces (87.2\%). En las hojas, el componente fenólico más alto se observó en la aplicación de control (56.9 $\pm 0.0 \mathrm{mg} \mathrm{GAE} \mathrm{g}^{-1}$ extracto seco), y el mayor contenido de flavonoides se detectó en la aplicación del CAN (107.4 $\mathrm{mg}$ de pirocatecol $\mathrm{g}^{-1}$ extracto seco). En todos los extractos analizados (hoja, raíz y semilla), las plantas fertilizadas presentaron contenidos flavonoides mayores que los obtenidos en la aplicación de control. Además, los extractos de la raíz del Abutilon indicum Sweet tuvieron la mejor actividad antibacteriana contra el Streptococcus pyogenes.

Palabras clave: Aceite crudo, actividad biológica, CAN, fertilizante, NPK, rendimiento.

\section{References}

Abdul, M.M., A.A. Sarker, I.M. Saiful, and A. Muniruddin. 2010. Cytotoxic and antimicrobial activity of the crude extract of Abutilon indicum. International Journal of Pharmacognosy and Phytochemical Research 2:1-4.

Brand-Williams, W., M.E. Cuvelier, and C. Berset. 1995. Use of a free radical method to evaluate antioxidant activity. Food Science and Technology-Lebensmittel-Wissenschaft \& Technologie. U.-Technol. 28:25-30.

Birman, H. 2012. Bioactivities of plant flavonoids and the possible action mechanisms. Journal of İstanbul Faculty of Medicine 75:46-49.
Chakraborthy, G.S. and P.M. Ghorpade. 2010. Free radical scavenging activity of Abutilon indicum (Linn) Sweet stem extracts. International Journal of Chem. Tech. Research 2:526-531.

Canadanović-Brunet, J., G. Ćetković, S. Đilas, V. Tumbas, V. Bogdanović, A. Mandić, S. Markov, D. Cvetkovic, and V. Canadanovic. 2008. Radical scavenging, antibacterial and antiproliferative activities of Melissa officinalis L. extracts. Journal of Medicinal Food 11:133-143.

Fisherman, F.W., and G. Cohen. 1973. Chemical intolerance to butylated hydroxyanisole (BHA) and butylated hydroxytoluene and (BHT) and vascular response as an indicator and monitor of drug intolerance. Annals of Allergy 31:126-133. 
Gulcin, I., M. Oktay, E. Kireçci, and I.O. Küfrevioglu. 2003. Screening of antioxidant and antimicrobial activities of anise (Pimpinella anisum L.) seed extracts. Food Chemistry 83:371-382.

Gurumurthy, H., Y.L. Ramachandra, and S. Padmalatharai. 2011. In-vitro antibacterial study on leaf extracts of Abutilon indicum Linn. Electronic Journal of Environmental, Agricultural and Food Chemistry 10:1892-1896.

$\mathrm{Hu}$, Y., and U. Schmidhalter. 2005. Drought and salinity: A comparison of their effects on mineral nutrition of plants. Journal Plant Nutrition and Soil Science 168:541-549.

James, C.S. 1995. Analytical chemistry of foods. Seale-Hayne Faculty of Agriculture, Food and Land Use Department of Agriculture and Food Studies Springer Science and Business Media B.V. University of Plymouth. 178 pp.

Marinova, D., F. Ribarova, and M. Atanassova. 2005. Total phenolics and total flavonoids in Bulgarian fruits and vegetables. Journal of the University of Chemical Technology and Metallurgy 40:255-260.

Mattson, N., and R. Leatherwood. 2009. Nitrogen: All forms are not equal. Cari Peters J.R. Peters Inc. p. 61.

Parrish, J.D.A., and F.A. Bazzaz. 1985. Nutrient content of Abutilon theophrasti seeds and competitive ability of the resulting plants. Oecologia (Berlin) 65:247-251.

Prescott, L.M., J.P. Harley, and D.A. Klein. 1990. Microbiology Antimicrobial Chemotheraphy. Wm. C. Brown Publishers, London, UK. p. 253255.

Porchezhian, E., and S.H. Ansari. 2005. Hepato protective effect of Abutilon indicum on experimental liver damage in rats. Phytomedecine 12:62-64.

Ponnudurai, K., K. Prabhu, and D. Prabu. 2011. Evaluation of anti-inflammatory activitiy of 75 percent $\mathrm{v} / \mathrm{v}$ methanolic extract of Abutilon inducum (Linn.) Sweet leaves. International Journal of Research in Ayurveda and Pharmacy 2:15741576.

Pandaya, S., T. Sharmin, S.R. Chowdhury, F. Islam, and M.A. Rashid. 2013. Antioxidant, throm- bolytic and membrane stabilizing activities of Abutilon indicum (L.) Sw. Journal of SUB 4:76-81.

Raman, B.V., A.S. Ramkishore, M.U. Maheswari, and T.M. Radhakrishnan. 2009. Antibacterial activities of some folk medicinal plants of Eastern Ghats. Journal of Pure and Applied Microbiology 3:187-194.

Ranjit, P.M.Y., A. Chowdary, H. Krapa, S. Nanduri, H. Badapati, K.P. Kumar, P. Bommadevara, and M. Kasala. 2013. Antimicrobial and antihelminthic activities of various extracts of leaves and stems of Abutilon indicum (Linn.) International Journal of Pharmaceutical \& Biological Archives 4:235-239.

Slinkard, K., and V.L. Singleton. 1977. Total phenol analyses: Automation and comparison with manual methods. American Journal of Enology and Viticulture 28:49-55.

Singh, D., and R.S. Gupta. 2008. Modulatory influence of Abutilon indicum leaves on hepatic antioxidant status and lipid peroxidation against alcohol-induced liver damage in rats. Pharmacology online 1:253-262.

Sharma, A., R.A. Sharma, and H. Singh. 2013. Phytochemical and pharmacological profile of $\mathrm{Abu-}$ tilon indicum L. Sweet: a review. International Journal of Pharmaceutical Sciences Review and Research 20:120-127.

Tripathi, P., A. Mishra, S. Dwivedi, D. Chakrabarty, P.K. Trivedi, R.P. Singh, and R.D. Tripathi. 2012. Differential response of oxidative stress and thiolmetabolism in contrasting rice genotypes for arsenic tolerance. Ecotoxicology and Environmental Safety 79:189-198.

Yasmin, S., M.A. Kashmiri, I. Ahmad, A. Adnan, and M. Ahmad. 2008. Biological activity of extracts in relation shiptostructure of pureisolates of $\mathrm{Abu}$ tilon indicum. Pharmaceutical Biology 46(1011):673-676.

Zareie, S., P. Golkar, and G. Mohammadi Nejad. 2011. Effect of nitrogen and iron fertilizers on seed yield and yield components of safflower genotypes. African Journal of Agricultural Research 6:3924-3929. 